\title{
Alternative Therapy of Animals - Homeopathy and Other Alternative Methods of Therapy
}

\author{
By Torleiv Løken
}

Department of Large Animal Clinical Sciences, Norwegian School of Veterinary Science, P.O. Box 8146 Dep., N-0033 Oslo.

\begin{abstract}
Alternative therapy of animals is described, in the meaning of alternatives to veterinary therapy traditionally accepted by veterinary faculties and schools and included in their curricula. Alternative therapy composes of different disciplines, of which homeopathy is emphasised in this presentation. Information is given on the use and interest of such therapy among veterinarians and animal owners. Homeopathy as other alternative therapies, may offer great advances, if they induce any effect. Some of the disciplines are based on a scientifically accepted documentation. Others, and homeopathy in particular, are missing such a documentation of effect. The justification of including alternative therapy in treating animals is discussed. Research in alternative therapy of animals is greatly needed, in particular to evaluate therapeutic methods which are in extensive use without any documented effect. An ongoing research project in Norway on the effect of homeopathic treatment of mastitis in cows is shortly presented.
\end{abstract}

Alternative therapy, homeopathy, animals, cow, mastitis, research, scientific evaluation.

This paper is on the alternative therapy of animals in general, and homeopathy in particular (Scotfield 1984). Many scientists, even at the Norwegian School of Veterinary Science $(\mathrm{NVH})$, maintain that alternative therapy is largely non-scientific and should not be of interest to serious scientists. Some experienced scientists even go so far as to claim that government employees should not be allowed to use their time on these alternative approaches to therapy in animals. However, it is important and it should be of interest for the traditional western medical world, including veterinary schools, to look more closely at the documentation of different alternative therapeutic methods in animals.

What is alternative therapy of animals? There is no clear-cut definition. A suitable description is that alternative therapy of animals encompasses methods of treatment that are not included in the traditional veterinary therapy as accepted and practiced in the curricula of veterinary faculties or schools, i.e., it is an alternative to "school medicine".. However, it should be stressed that there is no clear-cut border between alternative medicine and school medicine. Furthermore, the boundaries between the two forms of therapy change with time, so that alternative therapy of animals should be considered with a more open view. The alternative methods of therapy referred to above include a wide range of disciplines. The best known and most commonly practiced are: 1) Acupuncture; 2) Chiropractic; 3) Phytotherapy; 4) Homeopathy.

1) Acupuncture is a method that is over 4000 years old. It originated in Eastern Asia, particularly China, but during the last century it has been practiced increasingly in Europe. It is now 
by far the most accepted and widely used alternative therapy in Europe, both in human and veterinary medicine. Over the last two decades, it has to some extent been integrated into school medicine. There are several courses available in acupuncture also at universities. Lately, there has been an initiative for such a course from the Veterinary school in Finland.

2) Chiropractic is a method of treatment for subluxations of the vertebral column. The clinicopathological entities evoked by subluxation in the vertebral column affect nerves and neuronal function and may influence normal movement. In the Nordic countries, quite a few veterinarians practice this discipline, mostly in small animals.

3) Phytotherapy involves the use of herbs or products of herbs and is also an old form of therapy. This form of treatment is a well-accepted method of therapy in both man and animals and until quite recently was often the only type of medicine available. Herbs have always been the basis for many medicaments and still are, although nowadays the synthetic production of most medicines is both cheap and efficient. The synthetic production of the modern medicines, however, often gives a result that in many aspects are far from any herb origin, as in purity and content.

4) Homeopathy is an alternative therapy that is experiencing a great increase in use. Supporters or "believers" in homeopathy claim that the method involves treatment of the whole individual or patient, or is taking care of him. It is a so-called holistic concept. Homeopathy includes some basic characteristics and theories that seem very peculiar or unfamiliar to someone educated in a traditional veterinary school. For example, the concept that "like cures like", which maintains that a drug which induces an intoxication has the ability to cure the same aliment, if it is used in high enough dilution! To be an effective medicine, the drug has to be extremely diluted. The medicine is composed mostly of an extract or solution that is serially diluted, for example, $1: 10$ or 1:100 between 10 to 100 times $\left(10^{10-100} ; 100^{10-100}\right)$. Generally speaking, the higher the dilution, the stronger the effect! To enhance the remedy, which homeopathic medicines are mostly called, it is important that each dilution step is followed by a particular and vigorous shaking, so-called "succussion".

How a homeopathic remedy induces its therapeutic effect is unknown, although there are some theories. One theory proposes that the energy in the patient is balanced or improved. Regardless, homeopathy offers some great advantages - if it works! In general, the use of a remedy that contains effectively no substance does not induce an allergic reaction or other side effects. There are no residue problems, no withdrawal period for the product and no environmental pollution. In addition, the remedies are relatively cheap.

Given these advantages, the acceptance and confidence in homeopathy should depend on the acceptance of a proven effect, but unfortunately for homeopathy this is not present. Many trials have been performed and several report a more or less positive effect (Persson Waller et al. 1999, Wynn 1998). However, it is probably correct to claim that so far a thorough scientific evaluation of the effect of homeopathic therapy has not been undertaken. How then can it be justified for veterinarians to work with such therapy on sick animals? Some claim it is not justified! As homeopathy is not a therapy with a scientifically proven effect, veterinarians and other medical personnel in Sweden do not have the legal right to use it. In a discussion in Sweden this year of the use of such therapies in animals, an editorial in the Swedish Veterinary 
Journal justifies scepticism against homeopathy (Beck-Friis 2000). On the other hand, the EU directive 1804/1999 imposes phytotherapy or homeopathy to be used in organic farming, if such methods have an effect.

In general, it should be obvious that veterinarians and doctors have to work according to scientifically documented principles including methods of therapy. However, when so-called academic "truths" and theories differ from many people's experience and honest conviction, criticism should be tempered. Critics of homeopathy should remember that history contains many examples of theories that were for a period widely accepted and claimed to represent the truth but subsequently have proven to be wrong. Sometimes the reality is so unbelievable that it is beyond most people's imagination. The dispute over whether the earth is flat or round is history but only 20 years ago belief in an "infectious protein" was considered irrational. Eminent scientists maintained that such an agent was unnatural and out of the question. In the modern vocabulary, such proteins are called prions and are the cause of spongiform encephalopathies, which include the frightening new variant of Creutzfeldt-Jacobs disease. Similarly, the 4000 year-old principle of acupuncture was "discovered" by the West and brought to Europe more than 100 years ago but has only started to be accepted by school medicine in the last 20 years after quite strong opposition. The conclusion must be that humility in regard to one's own knowledge and wisdom is advisable and that without valid documentation, other people's experience and knowledge should not be dismissed as untrue. In relation to homeopathy, a research project is being implemented at NVH on "Scientific evaluation of homeopathic treatment of infections in production animals". The Norwegian Research Council, through the Norwegian Centre for Organic Agriculture (NORSØK), has funded a 4-year doctoral programme, in which this research project will be included. A veterinarian has been employed at the Department of Large Animal Clinical Sciences. The main part of the project will address spontaneous mastitis in dairy cows in the field. The study has three main goals. The project will undertake the scientific evaluation of any effect of homeopathy on bovine mastitis, and also examine homeopathy as a means of reducing the use of antibiotics in the treatment of animals. The third goal to be addressed in the doctoral programme is to increase research competence in alternative therapy of animals, and in homeopathy in particular. Homeopathic therapy of mastitis cases will be compared with classical therapy using antibiotics, and a control group receiving no medication. The homeopathy group and the control group will be handled in a "double blind" arrangement for both the doctoral student and the therapist, who will be an experienced homeopath. The homeopath has been employed by the project to diagnose and treat cows according to the research plan. A local veterinarian will treat the antibiotic group. All cows in all groups will be milked frequently, which for the project will be five times a day for two days. Detailed criteria will be applied for the inclusion and exclusion of animals. The doctoral student will examine all cows at the time of inclusion and later at a few fixed times after treatment. The animals will be grouped according to defined strata, and in therapy groups at random. The project is planned in accordance with high scientific standard and international demands for controlled clinical trials. This project will represent the first step towards a scientific evaluation of homeopathic therapy of animals, and its effect on mastitis in dairy cows in particular. Hopefully, this project will provide an indication of a positive effect, or of no effect. Either way, it will certainly be an interesting and exciting project. 


\section{References}

Beck-Friis J: Välgrundad skepsis mot homeopati (Justified scepticism against Homeopathy). Svensk Vet.Tidn. 2000, 52 (10), 485.

Persson Waller K, Beyer W, Ekman T: Veterinar homeopati till landbrukets djur - en sammanstallning av vetenskapeliga forsok (Veterinary homeopathy to agricultural animals - a summary of scientific experiments). A report, Swedish University of Agricultural Sciences, Uppsala, 1999.

Scotfield AM: Homeopathy and its potential role in agriculture - a critical Review. Biol. Agric. and Horticulture 1984, 2, 1-50.

Wynn SG: Studies on use of homeopathy in animals. JAVMA 1998, 212 (5), 719-724.

\section{Samandrag}

Alternativ terapi hos dyr. Homeopati og andre alternative terapiformer

Alternativ terapi hos dyr er her omtala i meining av alternativ til veterinær terapi som er akseptert av veterinærskolar og -fakultet, og som er inkludert i deira undervisningsplanar. Alternativ terapi omfattar mange ulike disiplinar. I denne presentasjonen vert hovudvekta lagt på homeopati. Det vert gjeve informasjon om bruk og interesse av slik terapi hos veterinærar og dyreeigarar. Homeopati kan som andre alternative terapiformer gje store fordelar, om metoden har effekt. Nokre slike terapiformer har ein godt vitskapeleg dokumentert effekt, men andre og særleg homeopati manglar ein slikt basis. Grunnlaget for å inkludere alternativ terapi i veterinærbehandling av dyr vert diskutert. Det vert peika på eit stort behov for forsking innan alternativ terapi. Særleg er behovet stort for å granske og evaluere terapiformer som homeopati, som er i utstrakt og aukande bruk man manglar vitskapeleg dokumentert effekt. Til slutt gjev presentasjonen ei kort omtale av eit nyleg oppstarta forskingsprosjekt ved Norges veterinærhøgskole. Dette prosjektet vil vurdere effekten av homeopatisk behandling av mastitt hos mjølkeku. 